\title{
泌尿器科領域におけるポリアミン
}

第 2 報 尿路腫瘍及び前立腺肥大症における組織内ポリアミン

$\begin{array}{cllll} & \text { 湯 } & \text { 浅 } & & \text { 誠 } \\ \text { 德島大学医学部泌尿器科学教室 } & \text { 前 林 } & \text { 浩 } & \text { 次 } \\ \text { (主任:黑川一男教授) } & \text { 香 } & & & \text { 征 }\end{array}$

\section{POLYAMINES IN UROLOGICAL DISEASES}

Report 2. Tissue Polyamines In Urological Cancer and Benign Prostatic Hyperplasia

\author{
Makoto Yusasa, Koji Maebayashi and Susumu Kagawa \\ Department of Urology, School of Medicine, Tokushima University, Tokushima \\ (Director: Prof. K. Kurokawa)
}

Polyamin concentrations of human cancerous and non-cancerous tissues from the kidney, bladder and testis were measured. In a comparative evaluation of each organ, putrescine, spermidine and spermine in cancerous tissues were higher than in non-cancerous tissues. This finding suggests that cancerous tissue produces higher levels of polyamines.

In non-cancerous tissue of the organs studied, the spermine level was highest and the spermidine and putrescine levels followed it. The levels of spermine in the kidney and spermidine in the testis were highest among normal tissues.

On the other hand, polyamines concentration in benign prostatic hyperplasia, specially spermine, was significantly high, being three times more than that of cancerous tissues.

Regarding glandular or fibromuscular types of benign prostatic hyperplasia, spermine level in glandular type was twice more than that of fibromuscular type. This finding suggests that spermine is produced by the glandular part of benign prostatic hyperplasia.

要旨: 人の組織内ポリアミン濃度について, 正常組織と癌組織の別に検討した. 同種臓器の正常組織と癌組織 の比較では, put. spd. spm. ともすべて癌組織において有意に高值を示し, 癌組織における活発なポリアミン の産生を裏づけた。

癌組織では, put., spd., spm. とも各種臓器間に有意差は認められなかつたが, 正常組織に特けるポリアミン

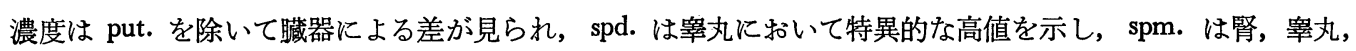
膀胱の順で各臓器間にはすべて有意差が見られた。 また組織内の各種ポリアミン濃度は, 正常組織, 癌組織と も, spm., spd., put の順であつた.

一方 BPH に括ける組織内ポリアミン濃度についても今回同時に検討したが，BPH 腺腫に扔けるポリアミ ン, 特に spm. 濃度は極めて高く, 他蔵器の癌組織と比較しても 3 倍以上の高值を示した. そのため, BPH の 組織内ポリアミン濃度については, BPH 腺腫を組織別に glandular type 及び fibromuscular type に分類しさ らに検討した. glandular type のBPH 腺腫に括ける spm. は fibromuscular type の腺腫の約 2 倍で他臟器の 癌組織と比べても約4.5倍もの高值を示し, spm. が BPH 腺腫の腺成分より活発に産生されていることを示し た.このことは精液中の spm. の働き及び BPH の成因等を考え合わせ, 極めて興味深かつた。

緒言

ポリアミンは細胞增殖と密接な関連があり近年新しい
腫瘍のマーカーとして注目を浴び，その臨床応用につい て種々の検討がなされているい゙3，すでにわれわれは， 
癌患者に打ける全血ポリアミン濃度について検討し報告 したが，臨床症例では，全血ポリアミン濃度の上昇は末 期癌患者にのみ認められ，早期癌患者では正常者との間 に有意の差は認められず全血ポリアミン濃度を癌の早期 診断に用いることは困難と思われた。

今回われわれは，人の組織内ポリアミン濃度を臟器別 にそれぞれ正常組織と癌組織に分けて putrescine, spermidine, spermine (以後 put., spd., spm. と略す) の別 に測定し，各群間の差異を比較検討するとともに，第 1 報にて報告した全血ポリアミン濃度の結果を合わせて考 察を加光, 若干の知見を得たので報告する.

また前立腺肥大症 (以後 BPH と略す) の腺腫は良性 腫瘍に属するが， BPH 患者では全血ポリアミン濃度が 正常者に較べ有意に高く, 極めて興味深いため, その腺 睡と被膜をBPH 群として別の 1 群を設け検討を行なつ た.

\section{対象}

対象は昭和53年 6 月より 54 年 12 月までの 1 年 6 カ月間 に当科にて手術を施行し，組織を入手し得た 77 症例 102 検体で，その年齢分布では最年少者は 24 歳, 最年長者は 81 歳で, 平均年齢は62.8歳であつた. 疾患別の内訳け は, 腎盎腫瘍 5 症例 7 検体, 膀胱腫瘍 9 症例 9 検体（組 織型は両群ともすべて 移行上皮癌), 鼻丸腫瘍 9 症例13 検体 (1 例両側性のものを含みその組織型は, 精上皮腫 5 症例 8 検体, 胎生癌 2 症例 2 検体, 䄉毛癌 1 症例 2 検 体, 奇型癌 1 症例 1 検体 であつた), 前立腺肥大症腺腫 (以後 BPH 腺腫と略す) 25症例25検体, 前立腺肥大症 外科的被膜 (以後 BPH 被膜と略す) 14症例14検体, 正 常腎 7 症例 8 検体, 正常膀胱 9 症例 9 検体, 正常辠丸 13 症例17検体であつた (Table 1).

摘出組織中肉眼的及び組織学的に全く異常所見の認め られないるのを正常群とし，腫瘍部分と別個に標本を採

Table 1 Distribution of age.

\begin{tabular}{|c|c|c|c|c|c|c|c|c|c|}
\hline & $\sim 29$ & $30 \sim 39$ & $40 \sim 49$ & $50 \sim 59$ & $60 \sim 69$ & $70 \sim 79$ & $80 \sim$ & total \\
\hline$\left|\begin{array}{l}0 \\
\vdots \\
\vdots \\
n \\
n\end{array}\right|$ & $k i d n \in y$ & & 1 & & 6 & & & & 7 \\
\hline$=$ & bladder & & & & 3 & 2 & 4 & & 9 \\
\hline : & test is & 4 & 1 & 1 & 2 & 1 & 3 & 1 & 13 \\
\hline . & pelvis & & & & 3 & 1 & 1 & & 5 \\
\hline $\mid \begin{array}{l}5 \\
\\
\end{array}$ & b ladder & & & & 3 & 4 & 2 & & 9 \\
\hline ü & test is & 2 & 3 & & 2 & & 1 & 1 & 9 \\
\hline 저 & a denoma & & & & & 6 & 17 & 2 & 25 \\
\hline & capsule & & & & & 3 & 9 & 2 & 14 \\
\hline
\end{tabular}

取し、それぞれの湿重量 $1 \mathrm{~g}$ 当りのポリアミン量を測定 して組織内ポリアミン濃度（単位 $\mathrm{nmol} / \mathrm{wet} \mathrm{g}$ ) とし, それぞれ put., spd., spm. の別に正常及び癌組織に拈け る各種臓器別の比較及び, 正常組織と癌組織間の差異に つき検討した。

一方, BPH 腺腫に和ける組織内ポリアミン濃度, 特 に spm. 濃度は特異的に高いレベルを示し，spm. が精 液産生等, 前立腺本来の働さと関連し興味が持たれた ため, BPH 腺腫の組織内ポリアミン濃度については, その組織像によりさらに 2 群に分類し検討した。すな わち，BPH腺腫に括ける fibrous element, muscular element, adenomatous element,cystic element等の各種成 分中, 腺成分を主体とするものを glandular type とし， それ以外の筋, 線維成分が優位なものを fibromuscular type として大別し，両群間の差異につき検討した. 両群の分別は組織学的に腺成分が50\%を超えるものを glandular type とし他を fibromuscular type として分類 した.なお， cystic element は glandular type の 1 亜型 と考えられ，glandular type に入れた. この分類による と, BPH 25例中 glandular type は14例 fibromuscular type は11例であつた.

な括すべての組織は切開手術によつて得られたものを 用い, TUR によるものは組織の損傷等を考慮して除外 した．また，統計処理はすべて $\mathrm{t}$ 検定を用い信頼度 $95 \%$ $(\mathrm{p}<0.05)$ にて行なつた.

\section{測定方法}

測定はダンシル化薄層クロマトグラフィー法を用い た4).この測定原理及び 詳細は検体の処理方法を除け ば，第 1 報にて報告した全血ポリアミン濃度の測定とほ ぼ同様である.すなわち，各組織の湿重量を測定後それ ぞれの重量の 9 倍量の $2 \%$ 過塩素酸 (PCA) を加兄， homogenization した後, 遠沈して，除蛋白を行ない， その上清を取り組織抽出液を得る。これ以後の操作は 全血ポリアミン濃度 の測定と 全く同様で, blank 及び standard とともに検体をダンシル化し，シリカゲル薄層 上に展開して put., spd., spm.の別に分離抽出後それぞ れの営光を測定し, blank, standard と比較して検体中の ポリアミン量を求める. 組織抽出液は測定過程にて200 倍に稀釈されているため，検体中のポリアミン量を200 倍して組織内ポリアミン濃度 (nmol/wet g) とする.

\section{結 果}

(A) 正常組織及び癌組織に括けるポリアミン濃度に sw. 
Table 2 Polyamine levels in tissues (Mean \pm S.D.)

\begin{tabular}{l|c|c|c|c|c}
\hline & Put & Spd & Spm & Total & Spd / Spm \\
\hline Kidney (N) & $56.4 \pm 28.0$ & $132.9 \pm 47.0$ & $500.6 \pm 89.0$ & $689.9 \pm 117.0$ & $0.27 \pm 0.08$ \\
Bladder (N) & $78.7 \pm 62.0$ & $118.1 \pm 46.0$ & $261.8 \pm 70.0$ & $425.6 \pm 116.0$ & $0.45 \pm 0.19$ \\
Testis (N) & $90.8 \pm 22.0$ & $265.2 \pm 47.5$ & $406.3 \pm 39.4$ & $776.9 \pm 88.7$ & $0.64 \pm 0.12$ \\
Pelvic Ca. & $112.1 \pm 68.0$ & $377.2 \pm 52.0$ & $973.0 \pm 408.0$ & $1411.9 \pm 510.0$ & $0.33 \pm 0.13$ \\
Bladder Ca. & $175.1 \pm 51.0$ & $412.6 \pm 221.0$ & $852.1 \pm 362.0$ & $1440.3 \pm 570.0$ & $0.53 \pm 0.23$ \\
Trans. C. Ca. & $147.6 \pm 40.0$ & $399.0 \pm 122.0$ & $905.0 \pm 238.0$ & $1427.9 \pm 552.0$ & $0.44 \pm 0.14$ \\
Testicular Ca. & $159.2 \pm 46.2$ & $468.4 \pm 92.0$ & $783.6 \pm 150.9$ & $1441.3 \pm 268.4$ & $0.66 \pm 0.10$ \\
BPH (Adenoma) & $184.4 \pm 46.8$ & $349.8 \pm 50.5$ & $3119.5 \pm 693.7$ & $3506.6 \pm 815.7$ & $0.11 \pm 0.02$ \\
BPH (Capsule) & $87.3 \pm 27.1$ & $148.2 \pm 50.6$ & $1263.3 \pm 578.4$ & $1523.7 \pm 636.3$ & $0.13 \pm 0.04$ \\
\hline
\end{tabular}

Fig. 1 Analysis of polyamines of tissues

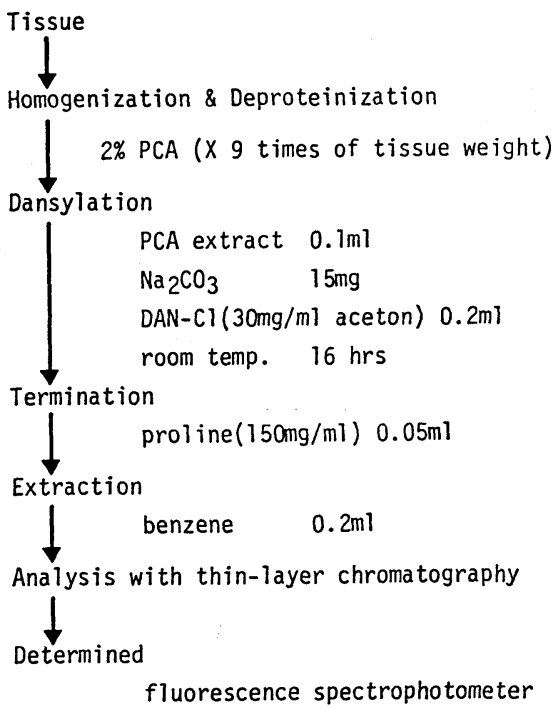

1) putrescine (Table 2, Fig. 2, Fig. 5)

a) 正常組織

正常組織中の put. 濃度は, 殬丸90.8土22.0nmol/wet $\mathrm{g}$, 膀胼 $78.7 \pm 62.0 \mathrm{nmol} /$ wet $\mathrm{g}$, 腎 $56.4 \pm 28.0 \mathrm{nmol} /$ wet $\mathrm{g}$ の順であつたが， 3 者の間には有意の差は認められなか つた.

\section{b ) 癌組織}

癌組織中の put. 濃度は, 腎孟癌 $112.1 \pm 68.0 \mathrm{nmol} / \mathrm{wet}$ $\mathrm{g}$, 膀脂癌 $175.1 \pm 51.0 \mathrm{nmol} / \mathrm{wet} \mathrm{g}$, 辠丸腫瘍 $159.2 \pm 46.2$ $\mathrm{nmol} /$ wet $\mathrm{g}$ であり, 組織学的診断が同じである 腎孟癌 と膀脱癌を移行上皮癌としてまとめると, その平均值は $147.6 \pm 40.0 \mathrm{nmol} /$ wet $\mathrm{g}$ であつた. 同種藏器の癌組織と
正常組織の間では明らかな有意差が認められ，すべて癌 組織に特いて高値を示したが, 癌組織間では藏器別の有 意差は認められなかつた。 また，殬丸腫瘍ではその組織 別に検討を行なつたが，症例数が少ないこともあつて有 意の差は見られなかつた.

\section{c) $\mathrm{BPH}$}

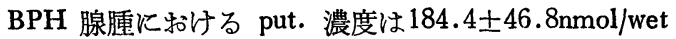
g と癌組織とほぼ同程度の高いレベルを示し, 他臓器の 正常組織と比較して有意に高値を示した. 一方 $\mathrm{BPH}$ 被 膜に括ける put. 濃度は87.3土27.1nmol/wet $\mathrm{g}$ と低く， 他の正常組織とほぼ同じレベルであり，腺腫と被膜の間 には明らかな有意差が見られた。また，腺腫では各測定 值間のバラつきが大きいが，put.が高值を示す症例は他 のポリアミンも高い傾向を示した.

2) spermidine (Table 2, Fig. 3, Fig. 5)

a) 正常組織

spd. は正常組織中睪丸組織に扣いて265.2士47.5nmol/ wet $\mathrm{g}$ と最も高值を示し, 腎132.9土47.0nmol/wet $\mathrm{g}$, 䠙 脱118.1土46.0nmol/wet g の順と†つているが, put. と は異なり，正常組織間でもかなりの差が見られ，辠丸内 spd. 濃度は, 他臓器と比較して有意に高值を示した。

b) 癌組織

癌組織における spd. 濃度は, 高い順に辠丸腫瘍 468.4 $\pm 92.0 \mathrm{nmol} /$ wet $\mathrm{g}$, 膀脂癌 $412.6 \pm 221.0 \mathrm{nmol} / \mathrm{wet} \mathrm{g}$, 腎 血癌 $377.2 \pm 52.0 \mathrm{nmol} / \mathrm{wet} \mathrm{g}$ （移行上皮癌 $399.0 \pm 122.0$ nmol/wet g) であり, 正常組織に較べると, 極めて高い レベルを示し, 同種臟器の正常組織との間にはすべて明 らかな有意差が認められたが，正常組織群とは異なり， 癌組織では各臓器間に有意の差はなく, 䉒丸腫瘍に打い 
Fig. 2 Putrescine levels in tissues

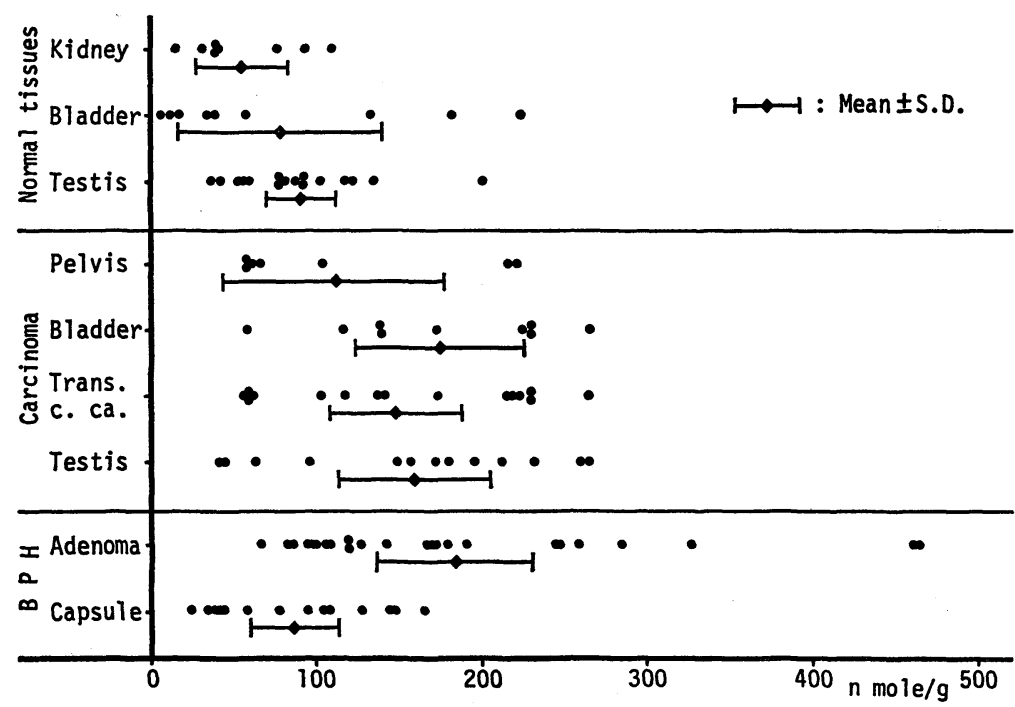

Fig. 3 Spermidine levels in tissues

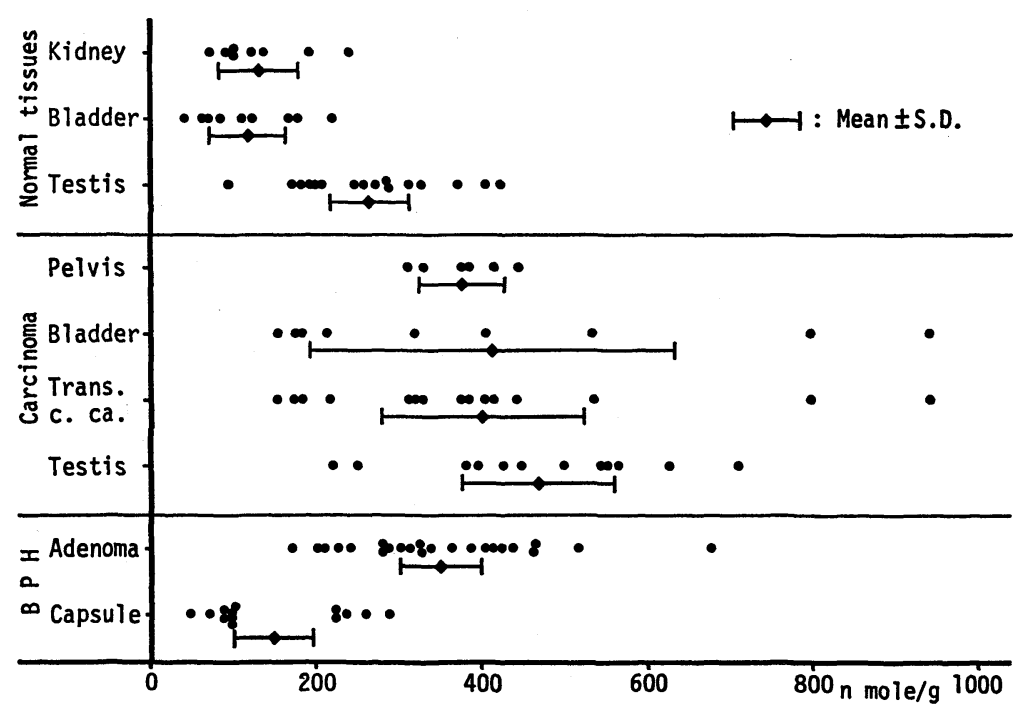

て,やや高値を示したのみであつた。

\section{c) $\mathrm{BPH}$}

BPH 被膜に打ける spd. 濃度は $148.2 \pm 50.6 \mathrm{nmol} / \mathrm{wet}$ $\mathrm{g}$ と正常組織に括ける spd. 濃度と同じレベルであつつ が, BPH 腺腫に扣ける spd. 濃度は349.8土50.5n mol/ wet $\mathbf{g}$ と他臓器の癌組織とほぼ同じ高いレベルを示し, 腺腫と被膜の間には明らかな有意差が認められた。

3) spermine (Table 2, Fig. 4, Fig. 6) a) 正常組織

正常組織に拈ける spm. 濃度は臓器により明らかな差 が見られ，高い方から順に，腎500.6 $\pm 89.0 \mathrm{nmol} /$ wet g, 呈丸 $406.3 \pm 39.4 \mathrm{nmol} / \mathrm{wet} \mathrm{g}$, 膀胱 $261.8 \pm 70.0 \mathrm{nmol} / \mathrm{wet}$ $\mathrm{g}$ であつたが, 各臓器間にはすべて 有意差が認められ た.

b) 癌組織

正常組織とは異なり, 癌組織では組織内 spm. 濃度の 
Fig. 4 Spermine levels in tissues

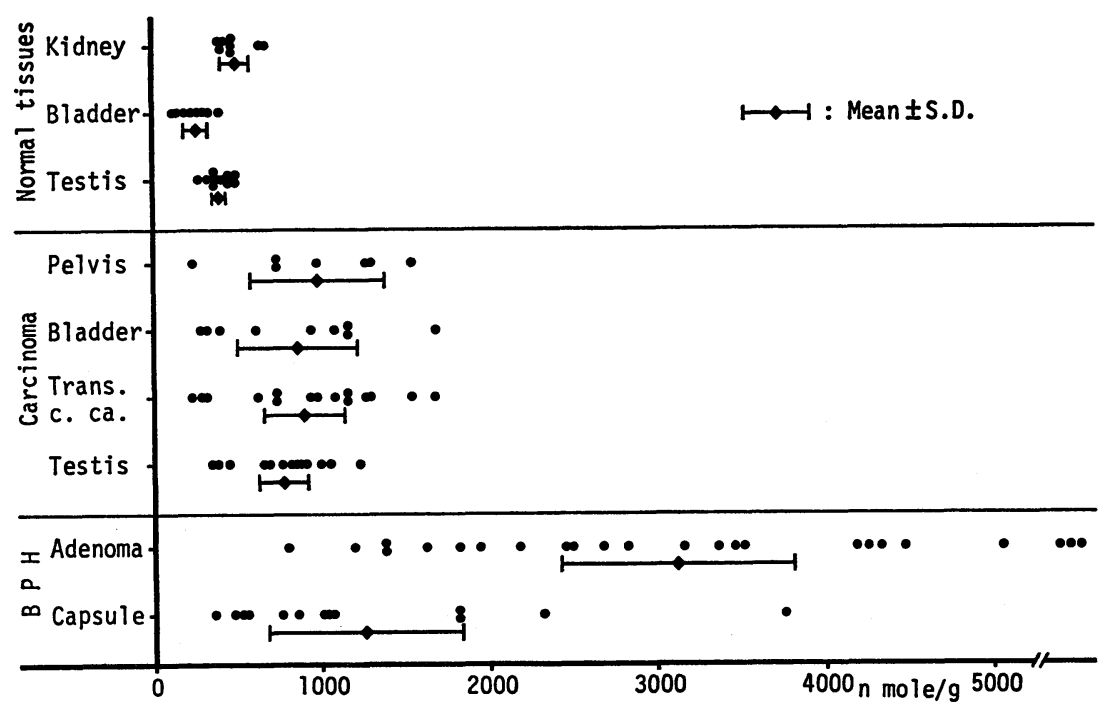

Fig. 5 Significant relationships with putrescine or spermidine in tissues

\begin{tabular}{|c|c|c|c|c|c|c|c|c|c|}
\hline & $\begin{array}{l}\text { Kidney } \\
\text { (N) }\end{array}$ & $\begin{array}{l}\text { Bladder } \\
\text { (N) }\end{array}$ & $\begin{array}{l}\text { Testis } \\
\text { (N) }\end{array}$ & $\begin{array}{l}\text { Pelvic } \\
\text { Ca. }\end{array}$ & $\begin{array}{l}\text { Bladder } \\
\text { Ca. }\end{array}$ & $\begin{array}{l}\text { Trans. } \\
\text { C. Ca. }\end{array}$ & $\begin{array}{l}\text { Testic- } \\
\text { ular Ca. }\end{array}$ & $\begin{array}{l}\text { B P H } \\
\text { Adenoma }\end{array}$ & $\begin{array}{l}\text { BPH } \\
\text { Capsule }\end{array}$ \\
\hline Kidney (N) & & N.S. & + & + & + & + & + & + & N.S. \\
\hline Bladder (N) & N.S. & & + & + & + & + & + & + & N.S. \\
\hline Testis (N) & N.S. & N.S. & & + & + & + & + & + & + \\
\hline Pelvic Ca. & + & + & N.S. & & N.S. & N.S. & N.S. & N.S. & + \\
\hline Bladder $\mathrm{Ca}$. & + & + & + & N.S. & & N.S. & N.S. & + & + \\
\hline Trans. C. Ca. & + & + & + & N.S. & N.S. & & N.S. & N.S. & + \\
\hline Testicular Ca. & + & + & + & N.S. & N.S. & N.S. & & + & + \\
\hline B P H (Adenoma) & + & + & + & N.S. & N.S. & N.S. & N.S. & & + \\
\hline BPH (Capsule) & N.S. & N.S. & N.S. & + & + & + & + & + & \\
\hline
\end{tabular}

臓器別の差は認められず, 腎孟癌 $973.0 \pm 408.0 \mathrm{nmol} /$ wet $\mathrm{g}$, 膀胱癌 $852.1 \pm 362.0 \mathrm{nmol} / \mathrm{wet} \mathrm{g}$ (移行上皮癌 $905.0 \pm$ $238.2 \mathrm{nmol} /$ wet g), 鼻丸腫瘍 $783.6 \pm 150.9 \mathrm{nmol} /$ wet $\mathrm{g}$ と ほぼ同じレベルであつたが，同種臓器の正常組織と癌組 織の間ではすべて明らかな有意差が見られた。

\section{c) $\mathrm{BPH}$}

BPH 腺腫における spm. 濃度は3119.5 wet $\mathrm{g}$ と他臟器の正常組織の 6 倍から10倍, 癌組織の 3 倍以上といら極めて高い值を示した，一方 BPH 被膜の spm. 濃度は $1263.3 \pm 578.4 \mathrm{nmol} /$ wet $\mathrm{g}$ で, 腺腫と比較 すると明らかな有意差が認められたが, 他臓器の正常組
織及び癌組織と比較すると有意に高い値を示した.

4) spd./spm. 比 (Table 2, Fig. 6)

a) 正常組織

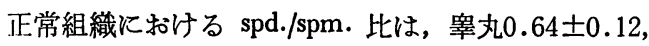
膀胱 $0.45 \pm 0.19$, 腎 $0.27 \pm 0.08$ 順であり, spd. 濃度の 高い奠丸に括いて最も高く, 逆に spm. 濃度の高い腎に おいて最低となつており，各群間にはすべて有意の差が 認められた。

b) 癌組織

癌組織に打ける spd./spm. 比も正常組織とほぼ同様の 傾向を示し, 南丸腫瘍における spd./spm. 比は0.66士 
Fig. 6 Significant relationships with spermine and spd/spm in tissues

\begin{tabular}{|c|c|c|c|c|c|c|c|c|c|}
\hline & $\begin{array}{c}\text { Kidney } \\
(N)\end{array}$ & $\begin{array}{c}\text { Bladder } \\
\text { (N) }\end{array}$ & $\begin{array}{l}\text { Testis } \\
\text { (N) }\end{array}$ & $\begin{array}{l}\text { Pelvic } \\
\mathrm{Ca} \text {. }\end{array}$ & $\begin{array}{l}\text { Bladder } \\
\text { Ca. }\end{array}$ & $\begin{array}{l}\text { Trans. } \\
\text { C. Ca. }\end{array}$ & $\begin{array}{l}\text { Testic- } \\
\text { ular Ca. }\end{array}$ & $\begin{array}{l}\text { B P H } \\
\text { Adenoma }\end{array}$ & \begin{tabular}{|l} 
BPH \\
Capsule \\
\end{tabular} \\
\hline Kidney (N) & & + & + & N.S. & + & + & + & + & + \\
\hline Bladder (N) & + & & + & N.S. & N.S. & N.S. & + & + & + \\
\hline Testis (N) & + & + & & + & + & + & N.S. & + & + \\
\hline Pelvic Ca. & + & + & + & & N.S. & N.S. & + & + & + \\
\hline Bladder Ca. & + & + & + & N.S. & & N.S. & + & + & + \\
\hline Trans. C. Ca. & + & + & N.S. & N.S. & N.S. & & + & + & + \\
\hline Testicular $\mathrm{Ca}$. & + & + & + & N.S. & N.S. & N.S. & & + & + \\
\hline B P H (Adenoma) & + & + & + & + & + & + & + & & N.S. \\
\hline B PH (Capsule) & + & + & + & + & + & + & + & + & \\
\hline
\end{tabular}

Table 3 Polyamine bevels in BPH (Mean \pm S.D.)

\begin{tabular}{|c|c|c|c|c|c|}
\hline & Put & Spd & Spm & Total & Spd / Spm \\
\hline B P H (Adenoma) & $184.4 \pm 46.8$ & $349.8 \pm 50.5$ & $3119.5 \pm 693.7$ & $3506.6 \pm 815.7$ & $0.11 \pm 0.02$ \\
\hline B P H (Capsule) & $87.3 \pm 27.1$ & $148.2 \pm 50.6$ & $1263.3 \pm 578.4$ & $1523.7 \pm 636.3$ & $0.13 \pm 0.04$ \\
\hline × $\begin{array}{l}\text { Glandular } \\
\text { 㯊 type }\end{array}$ & $223.8 \pm 75.6$ & $407.9 \pm 71.5$ & $4169.1 \pm 901.9$ & $4780.7 \pm 966.1$ & $0.10 \pm 0.02$ \\
\hline $\begin{array}{l}\text { ֻ } \text { Fibromus- } \\
\text { cular type }\end{array}$ & $119.0 \pm 25.8$ & $286.4 \pm 58.4$ & $1815.1 \pm 467.1$ & $2220.2 \pm 514.9$ & $0.16 \pm 0.04$ \\
\hline
\end{tabular}

Fig. 7 Polyamine levels in grandular type and fibromuscular type of BPH

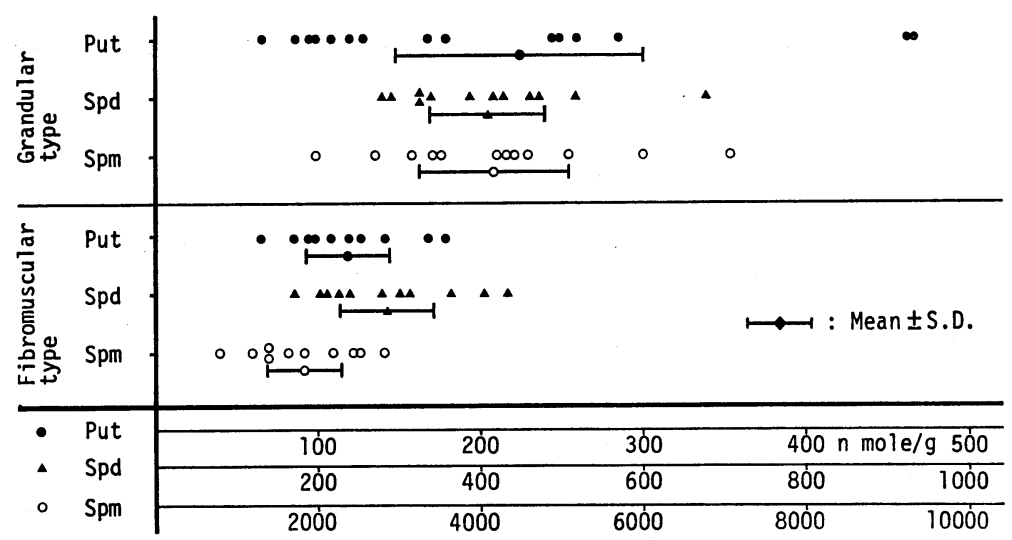

0.10 と高く, 膀脂癌の $0.53 \pm 0.23$ 及び, 腎盉癌の $0.33 \pm$ 0.13 と比較すると有意差が見られた. 一方同種臟器の正 常組織と癌組織を比較すると, すべて有意の差は見ら れず, spd. と spm. はともに平行した上昇を示してお り spd./spm. は, 臓器による特異性があるものと思われ た.

\section{c) $\mathrm{BPH}$}

BPH 腺腫における spd./spm. 比は $0.11 \pm 0.02$ と極め て低値を示し, 他藏器との間には有意の差が認められた が, BPH 被膜に和ける spd./spm. 比も0.13土0.04と低 く腺腫と被膜の間には有意の差は見られなかつた。

(B) BPHに拉ける組織内ポリアミン濃度について 
glandular type の各種ポリアミン濃度は, put. 223.8 $\pm 75.6 \mathrm{nmol} /$ wet $\mathrm{g}$, spd. $407.9 \pm 71.5 \mathrm{nmol} /$ wet $\mathrm{g}$, spm. $4169.1 \pm 901.9 \mathrm{nmol} /$ wet gであり, spd. 以外のポリアミ ンは極めて高く, 特に spm. は他臟器の正常組織と比べ て 8 倍から16倍, 癌組織と比較しても約4.5倍もの特異 的な高值を示した. 一方 fibromuscular type 飞和ける各 種ポリアミン濃度は put. 119.0 $25.8 \mathrm{nmol} /$ wet g, spd. $286.4 \pm 58.4 \mathrm{nmol} /$ wet $\mathrm{g}$, spm. $1815.1 \pm 467.1 \mathrm{nmol} /$ wet $\mathrm{g}$ であり，両群を比較すると glandular type は put. では fibromuscular type の約1.8倍, spd. では約1.4倍, spm. では約 2.3 倍もの高值を示して括り，すべて明らかな有 意差が見られた。 また， fibromuscular type の腺腫と BPH 被膜に拈ける各種ポリアミン濃度を比較すると, put., spd., spm. とも fibrpmuscular type の腺腫において 有意に高值を示した. spd./spm. 比では glandular type, fibromuscular type 及び BPH 被膜の間では有意の差は 認められなかつた。

\section{考案}

(A) 正常及び癌組織におけるポリアミン濃度につい $\tau$

今回われわれが測定した臟器は, 腎, 殬丸, 膀胱の 3 種であるが，これら組織内各種ポリアミン濃度はすべて spm., spd., put. の順であり, これは諸家の報告 ${ }^{5 / 6) 7)}$ 同様である．正常組織間に拈ける各種ポリアミン濃度の 比較では put. は各臟器間に有意の差は認められなかつ たが，spd.は鋅丸に和いて特異的に高く，他蔵器との間 には有意差が見られた。また，spm．は腎，悬丸，膀脱 の順で，3 者の間にはすべて有意差が見られ，臓器特異 性が認められた。

一方正常膀胱に怙ける組織内ポリアミン濃度は他臓器 と比較すると極めて低值を示したが，これは膀胱組織で はコラーゲン等の間質成分が多く, 組織内細胞密度が小 さいためではないかと考兄られ, 各種臓器内のポリアミ ン濃度は，DNA，RNA または蛋白質濃度等を考慮に入れ た単位での比較がより適切ではなかつたかと考える。

同種臟器の正常組織と癌組織に挌けるポリアミン濃度 を比較すると, put., spd., spm. とも癌組織に扔いて有 意に高值を示し, 癌組織に㨟ける活発なポリアミンの産 生を示すとともに，癌患者に淤ける各種体夜中のポリア ミン濃度の増加を裏づけるものであつたが，血中ポリア ミン濃度は，われわれも第 1 報にて報告した通り，進行 癌患者や, 放射線療法, 化学療法等の治療に際してのみ 上昇し，今回報告したような組織でのポリアミンの産生
を直接的に反映するものではなかつた。これは，ポリア ミンの代謝，排泄等の因子の関与によるものと考兄られ る.

Ferioli $^{8)}$, Janne ${ }^{9)}$ らは， spd./spm. 比が細胞増殖と密 接な関連があると報告しており，また松田らは，spd./ spm. 比は細胞の分化の程度が低い注ど(0)大きくなると 報告しているが，われわれの検討では，それを裏づける ような結果は得られず，ただ細胞增殖能の高いと思われ る辠丸組織に䄧いて spd./spm. 比が有意に高值を示した に過ぎなかつた. なお spd./spm. 比は, 各種蔵器間です べて有意差が見られ，葴器特異性を示す点で興味が持た れた。

(B) BPH に抢兴組織内ポリアミン濃度について 今回のわれわれの検討では，前立腺肥大症における組 織内ポリアミン濃度, 特に spm. 濃度は, その腺成分に おいて有意に高いことが実証されたが，このことは，こ れらの腺組織に招いてポリアミンが活発に産生されてい ることを示すものであり，ポリアミンの持つ蛋白や，核 酸合成に対する一種の補酵素的な働きを考兄ると，BPH の腺腫は，極めて活動的な腺細胞の集団であると言兄 る. BPH の成因については諸説があり，未だ完全には 解明されていない. Moore ${ }^{11)}$ は， BPH は前立腺の中葉 及び側葉の尿道周囲の部より発生すると報告して沏り， この見解は現在広く支持されているが，この発生母地に ついては，Moore のように真の前立腺より発生するとす る意見と, 真の前立腺とは明らかに異なる, 内腺と呼ば れる全く別の腺組織から発生するという意見 ${ }^{12}$ があり， 最近の研究 ${ }^{13) 14}$ でもこの点に関しては意見の一致を見て いないまた，内腺の本来の働きについても，な抗その 詳細は不明である. 完成した BPH の腺腫は成人の前立 腺之構造上極めて類似して扮り, その機能についても, Moor ${ }^{15)}$ は巨視的な測定結果ではあるが，本来の前立腺 液とほとんど同様の液を分泌していると報告している. しかしながら，この点に関しても，詳細な報告は少な く，な扮不明な点が多い。しかし，BPH の腺腫に佂け る多量のポリアミン産生と, 人の精液中の高濃度のポり アミンは, BPH の発生母地とされる内腺が，単なる粘 液腺ではなく, 本来何らかの生理的な 分泌機能を持っ た，活動性のある腺組織であることを推測させるもので ある。

正常者に拈ける精液中の平均ポリアミン濃度は, William ${ }^{16)}$ とよると, spd. $214 \mathrm{nmol} / \mathrm{ml}$, spm. 1,352nmol/ $\mathrm{ml}$ であり, この值を BPH の組織内ポリアミン濃度 
と比較すると, glandular type の腺腫の1/2〜1/3で, fibromuscular type の腺腫と BPH 被膜の中間の值であ る.このことも精液中のポリアミンが, 前立腺の腺成分 より分泌されたものである事を示す 1 つの裏づけと考元 られるが，正常前立腺に执いて，ポリアミンが内腺のみ 上り分泌されるものか, 内腺, 外腺の両者より分泌され るものかは不明で， BPH の成因と合わせ，今後の検討 が待たれる.

精液中のポリアミンについても，未だ充分な解明はな されて打らず，定説はないが，William ${ }^{16)} ら は$ 精液中 のポリアミンは精子の運動と関連し, 不妊症ではポリア ミンの低值と相関して運動率の低下が見られると報告し ている.これについては, 相反するよらな報告 ${ }^{17)}$ 見ら れ, さらに詳細な検討が待たれる所であるが，前立腺に 护ける多量のポリアミンの産生及び, 精液中の高濃度の ポリアミンを考台合わせると，精液中のポリアミンが何 らかの生理的役割を担つていることは充分に考えられ， 興味の持たれる所である。

\section{結 語}

1）正常組織（腎, 膀胱, 曾丸) に批ける各種ポリア ミン濃度は,すべて spm.>spd.>put. の順であり, put。 では各臓器間に有意の差はなく, spd.は粹丸において有 意に高值を示し腎, 膀胱では差はなく, spm. は腎, 辠 丸, 膀胱の順で 3 者の間にはすべて有意差が見られた。

2) 同一臟器の正常組織 と癌組織の間では, put., spd., spm. ともすべて癌組織に拮いて有意に高く, 癌組 織に拈ける活発なポリアミン産生を裏づけるものであつ た.

3） BPH における組織内ポリアミン濃度, 特に spm. 濃度は特異的に高く, 他臓器の癌組織と比較しても 3 倍 以上の高値を示した.

4） BPH を組織成分により glandular type と fibromuscular type 飞大別し，それぞれの組織内ポリアミン 濃度を比較すると put., spd., spm. とも glandular type に执いて有意に高値を示し, ポリアミンがこれらの腺に より産生されていることを示した。

（稿を終えるにあたり, 御指導, 御協力下さった德島 大学歯学部生化学教室の竹田義郎教授, 井上秀夫助教授 に深く感謝致します。な技本論文の要旨は第68回日本泌 尿器科学会総会において発表した).

\section{文 献}

1) Russel, D.H., Levy, C.C., Schimpff, S.C. and Hawk, I.A.: Urinary polyamines in cancer patients. Cancer Res., 31, 1555-1558, 1971.

2) 植原典美, 佐伯行一, 白川 茂, 堂前尚親, 内 野治人：癌患者に打ける赤血球ポリアミン量の 検討。医学のあゆみ, 107, 23-25, 1978.

3) Russell, D.H., Durie, G.G.M. and Salmon, S.E.: Polyamines as predictors of success and failure in cancer chemotherapy. Lancet, 2, 797-799, 1975.

4) 井上秀夫, 竹田義郎, 大工原恭：ポリアミン, 生化学実験講座11, 一アミノ酸代謝と生体フミ ン（下)—, 951-994, 1976.

5）化田正和, 仲西義祐, 唃上昌男, 御供泰治, 山 本正治：老化とポリアミン．医学のあゆみ, 109, 552-554, 1979.

6) 松田 稔, 長船匡男, 中野悦次, 園田孝夫, 清 原久和, 古武敏彦：ヒ下腎細胞癌の基碟的研 究, 第 4 報, 腫海組織内ポリアミン類の含量に ついて. 泌尿紀要, 25, 1239-1245，1979.

7) Udo Duzendorfer and Diane Haddock Rurrell: Alterd polyamine profiles in prostatic hyperplasia and in kidney tumors. Cancer Res., 38, 2321-2324, 1978.

8) Maria Elena Ferioli and Roberto Comolli: Changes of liver and kidney polyamine levels during ageing. Exp. Gront., 10, 13-15, 1974.

9) Janne, J., Raina, A. and Siimes, M.: Spermidine and spermine in rat tissue at different ages. Acta. Physiol. Scand., 62, 352-358, 1964.

10) Minoru Matsuda, Masao Osafune, Tosihiko Kotake, Takao Sonoda, Kengi Sobue and Teruo Nakajima: Concentrations of polyamines in renal cell carcinoma. Clinica. Chimica. Acta., 87, 93-99, 1978.

11) Robert A. Moore: Benign hypertrophy of the prostate. A morphological study. J. Urol., 50, 680-710, 1943.

12) I.E. LeDuc, M.D.: The anatomy of the prostate and the pathology of early benign hypertrophy. J. Urol., 42, 1217-1241, 1939.

13) John E. Mcneal: The prostate and prostatic urethra. A morphologic synthesis. J. Urol., 107, 1008-1016, 1972.

14) John E. Mcneal: Origin and evolution of benign prostatic enlargement. Invest. Urol., 15, 340-345, 1978.

15) Robert A. Moore, Mary L. Miller and Allister McLellan: The chemical composition of prostatic secretion in relation to benign hypertrophy of the prostate. J. Urol., 46, 132-137, 1941.

16) William R. Fair, M.D., Robert B. Clark and Nancy Wehner: A correlation of seminal polyamine levels and semen analysis in the human. Fertility and Sterility, 23, 38-42, 1972. （1981年12月10月受付, 特別揭載） 